\title{
EFFECT OF THE LANDSCAPE TYPES ON HUNTING SELECTION IN ROE DEER (CAPREOLUS CAPREOLUS, LINNAEUS 1758) TROPHIES IN CZECH REPUBLIC
}

\author{
JENS H. ENGAN \\ Dønski High School, Rudsveien 73, NO1309 Rud, Norway, email: jens.engan@ \\ donski.vgs.no
}

Received: $22^{\text {nd }}$ April 2013, Accepted: $2^{\text {nd }}$ November 2014

\begin{abstract}
Czech Republic has a long tradition of hunting, and trophy hunting is important to manage game populations. In this study data was analysed from the five last trophy exhibitions in Czech Republic. Namely, hunter selection, compensatory selection, management selection, hunting pressure selection and depletion selection was tested in different landscape types. In compensatory hunting there is a difference between the landscape types; apparent differences exist between the landscape type with respect to hunting pressure. There was no hunter selection, or depletion selection, and no differences in management between landscape types. This study suggests that the landscape composition has an effect on selective hunting in Czech Republic.
\end{abstract}

Keywords: Landscapes, Hunting selection, Czech Republic, Roe deer, Capreolus capreolus

\section{INTRODUCTION}

All animals occupy landscapes, and landscapes are complex mixtures of physical and cultural unit. In Czech Republic, a landlocked country in central Europe, centuries of land-use changes have altered the landscape. The changes have, for example, occurred within open landscapes like agricultural land, and artificial landscapes like towns, railways and roads. The changes have also affected the wildlife species. The opening of the landscape has also changed the act of hunting, from hunting in forests to fields, with better visual conditions for the hunter.

An important species in the Czech landscape is roe deer (Capreolus capreolus). This species is distributed throughout the country, and every year, Czech hunters remove 99,000 to 121,000 specimens during the hunting season (Červený et al., 2009). Roe deer is an important component of game hunting in Czech Republic, as well as for trophy hunting. In the Natura Viva exhibitions in Lysa nad Labem in 1996, 2000, 2005 and 2009, and the exhibition in Česke Budejovice in 1993 inclusive, there were 2,656 roe deer trophies recorded from the entire country (CMMJ 1993, 1996, 2000, 2005, 2009). Czech Republic has a long tradition of hunting (Bartoš, 2010), and the country is one of most coveted hunting countries in Europe. However, roe deer is not the most important game species in Czech Republic, but together with wild boar (Sus scrofa) the most numerous. The most important 
game is the red deer (Cervus elaphus) and mouflon (Ovis musimon); especially the latter, where Czech Republic has the current world record, and have most of the leading trophies in the world (Červeny et al., 2009; Varicak, 2007). Czech Republic also has a long tradition for trophy exhibitions (local, national and international), and in the local exhibitions which are held every year, all trophies are measured.

Roe deer habitat is mainly woodland, however changes in anthropogenic land use during the last millennium, with increasing urban and agricultural areas, have forced the species to utilise new habitats.

\section{Hypothesis}

In this study, the following hypotheses will be tested:

Hunting selection:

H1: Hunters selection; P1 hunters will select larger individuals; this will give a negative correlation between relative antler size and relative age (measured as standard deviation) (Rivrud, 2013; Coltman, 2003)

H2: Compensatory hunting selection: P2: money talks, hunters will pay more money for larger trophies (trophy hunting) and there will be pressure to increase the quality of trophies by harvesting lower quality specimens in lower age groups (Rivrud, 2013; Mysterud \& Bichoff, 2010). This is described in Czech act of game management $\$ 6.2$ (Ministry of agriculture, 2001) and Babička et al. (2007)

H3: Depletion hunting selection; P3: Trophy size will decrease over years, with no recovery when the hunting pressure becomes weaker (Coltman et al., 2003; Rivrud, 2013)

H4: Hunting pressure selection: P4: Trophy size will decrease over time when hunting pressure is high, however the trophy size will recover when the hunting pressure becomes weaker (Vanpe et al., 2007; Rivrud, 2013)

H5: Management hunting selection: P5: Trophy size will be stable between years (Mysterud $\&$ Bischoff, 2010), however; the sign of the quadratic selection (Walsh, 2007) can calculate a weak selection (stabilisation selection or disruptive selection). A negative sign will indicate stabilisation selection and a positive sign will indicate disruptive selection.

\section{Landscapes}

L1: Are there differences in strength of hunting selection between landscape types in Czech Republic? PL1:

L2: In respect to landscape composition (occurrence of urban, agricultural and natural/semi-natural land), how could it have an effect on hunting selection

L3: The effect of edge density, patch density and mean patch size (forest) and landscape diversity on hunting selection 


\section{MATERIALS AND METHODS}

\section{Material}

The material consists of 2,640 roe deer trophies taken in Czech Republic in the period 1990 to 2008. The trophies were shown at the trophy exhibitions in Ceske Budejovice in 1993 and Lysa nad Labem in 1996, 2000, 2005 and 2009. Experts from Czech-Moravian Hunting Association (CMMJ) and the International council of wildlife conservation (CIC) measured the trophy specimens. The data from 2005 and 2009 are electronic and can be found at www.myslivost.cz, or in the trophy catalogues (CMMJ 2005, 2009). The data from 1993, 1996 and 2000 can be found in the trophy catalogues (CMMJ 1993, 1996, 2000); all trophies are medal bucks (CIC points above 105). The trophy measuring protocol can be found in Varicak (2007) or CIC red book (Whitehead et al., 1981). All stalking locations were localised by latitude and longitude of the hunting grounds in Czech Republic. (http://apps.hfbiz.cz/apps/mysliveckyportal/honitby/view/).

\section{Landscapes}

Corine land cover 2006 version 16 (EEA, 2012) was used, as well as Q-GIS version 2.4 (QGIS, 2014). Grids measuring $40 \mathrm{X} 40 \mathrm{~km}$ were used, along with reference system ETRS89-LAEA (EEA, 2014). The corine classes 1.1.1 to 1.4.2 were calculated as "urban"; classes 2.1.1 to 2.4.4. were calculated to "agricultural land", classes 3.1.1 to 3.1.3 were calculated to "forest", 3.2.1 to 4.2.3 were calculated to "other natural land" and 5.1.1 to 5.1.2 were calculated to "water" (see example Estreguil et al. 2012 or appendix for details). Every grid was recalculated to a landscape type after this triangulation, see Figure 1 and Table 1 (Estreguil et al., 2012).

\section{Fig. 1: Classifications of landscape types}

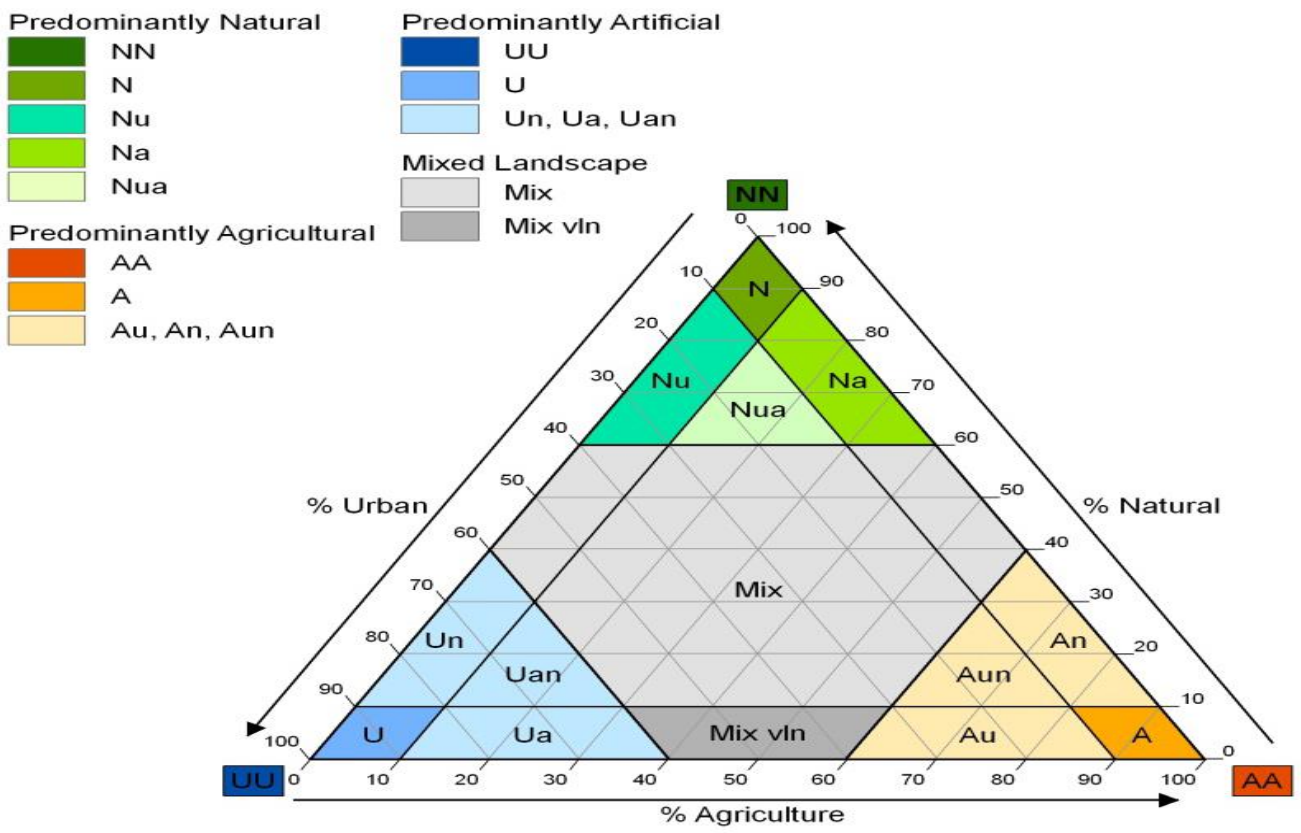

Where these landscape types were recognised: Aun, An, Na and mix 
Engan J. H.: Effect of the landscape types on hunting selection in roe deer (Capreolus capreolus, Linnaeus 1758) trophies in Czech Republic

\section{Table 1: Classifications of landscape types in Czech Republic}

\begin{tabular}{|l|l|l|l|}
\hline Landscape type & Agricultural land & Urban & Natural \\
\hline $\begin{array}{l}\text { Agricultural dominated land } \\
\text { with some natural land (An) }\end{array}$ & $60-90 \%$ & $0-10 \%$ & $10-40 \%$ \\
\hline $\begin{array}{l}\text { Agricultural dominated land } \\
\text { with some urban and } \\
\text { natural land (Aun) }\end{array}$ & $60-80 \%$ & $10-30 \%$ & $0-30 \%$ \\
\hline Mixed landscape (mix) & $0-60 \%$ & $0-60 \%$ & $10-60 \%$ \\
\hline $\begin{array}{l}\text { Natural dominated land with } \\
\text { some agricultural land (Na) }\end{array}$ & $10-40 \%$ & $0-10 \%$ & $60-90 \%$ \\
\hline
\end{tabular}

These grids was converted to geographical coordinates (WGS84) by using the internet page http://epsg/3035/map.io.

The commonly-used landscape ecology indices were calculated (http://www.umass.edu/ landeco/teaching/landscape_ecology/schedule/chapter9metrics.pdf), namely edge density:

$$
\sum_{1}^{\infty} \frac{l}{A * 10000}
$$

where $l$ is total length of patch type (forest and transitional wooded scrub) and A is total landscape area (160000 ha) per grid. Patch density n/A was used, where $n$ is number of patches (forest, wooded transitional scrub) and $\mathrm{A}$ is total area. Mean patch size Ai/n, where $\mathrm{Ai}$ is area of forest and transitional scrub and $\mathrm{n}$ is number of patches. Finally, Shannon diversity index was used to calculate landscape diversity.

$$
S H D I=-\sum_{i=1}^{m}(P i * \ln P i)
$$

Where $m=$ number of patch types

$\mathrm{P}_{\mathrm{i}}=$ proportion of area covered by patch type (land cover class)

All landscape calculations were completed in the LecoS module in QGIS (QGIS, 2014).

Hunter selection was calculated in the NUTS regions in Czech Republic and correlated to edge density, patch density, mean patch size and landscape diversity.

\section{Hunting selection}

The hunter selection was calculated (standardised CIC) with antler size and age as the independent and dependent variable, respectively. A negative slope indicates a negative hunter selection, whereas a positive slope indicates a positive hunter selection. For landscape type and for NUTS regions: CZ02: Central Bohemia; CZ03: Southwest Bohemia (Plzen and South Bohemia regions); CZ04: Northwest Bohemia (Carlsbad and Usti regions); CZ05: Northeast Bohemia (Pardubice, Hradec Kralove and Liberec regions); CZ06: South Moravia (South Moravia and Vyšocina regions); CZ07 : Central Moravia (Olomouc and Zlin regions); CZ08: Silesia-Moravia, CZ01: Prague is excluded from the analysis. 


\section{Compensatory hunting selection}

Selective hunting figures in Czech Republic are shown in Table 2 (after Babička et al., 2007).

Table 2: Selection for breeding of roe deer in Czech Republic in different age classes

\begin{tabular}{|c|c|c|c|c|}
\hline Age & Beam length & Number of tines & Tine length & Auxiliary characters breeding \\
\hline 1 & $10 \mathrm{~cm}$ & 2 & - & \multirow{7}{*}{$\begin{array}{l}\text { The benefit is for 2-year-old is considered a length of } \\
1.5 \mathrm{~cm} \text {, with } 3 \text {-year older, } 2 \mathrm{~cm} \text { in length, extremely } \\
\text { high quality in sense of high pearling, strong } \\
\text { coronets, regularity of antlers, exceptionally high } \\
\text { mass and force antler is a significant feature of } \\
\text { breeding at lower length of beams, with annual roe } \\
\text { deer does not consider pucks under } 1 \mathrm{~cm} \text { for the tines }\end{array}$} \\
\hline 1 & $7 \mathrm{~cm}$ & 3 & $1 \mathrm{~cm}$ & \\
\hline 2 & $15 \mathrm{~cm}$ & 4 & $3 \mathrm{~cm}$ & \\
\hline 2 & $15 \mathrm{~cm}$ & 5 & $2 \mathrm{~cm}$ & \\
\hline 3 & $20 \mathrm{~cm}$ & 6 & $3 \mathrm{~cm}$ & \\
\hline $4-5$ & $22 \mathrm{~cm}$ & 6 & $4 \mathrm{~cm}$ & \\
\hline 6 & $23 \mathrm{~cm}$ & 6 & $5 \mathrm{~cm}$ & \\
\hline
\end{tabular}

For analysing compensatory hunting, the percentage of antler size (1.28 Standard deviation of the CIC) was used, and the percentage in each landscape type was analysed. An ANOVA was calculated for landscape type as factor and age as covariate, and number of +1.28 standard deviation (close to the gold challenge in the CIC system) trophies (trophy hunting) and -1.28 standard deviation (compensatory hunting). A t-test was used to compare the different landscape types. See appendix for details.

\section{Management hunting selection}

Linear regression CIC (standardized): $\alpha+\beta *$ year , was used to analyse how stable the quality has been over the years, and quadratic regression distinguished stable and disruptive selection: CIC (standardized) $=\alpha+\beta *$ year $+\beta 2 *$ year $*$ year, where $\beta, \beta 2$ and $\alpha$ are constants. If the quadratic component is negative, it is stabilisation selection, and if positive, it is disruptive selection (Walsh, 2007).

\section{RESULTS}

\section{Landscapes}

The results are shown in Figure 2. Out of 66 grids, 30 grids where classified as mixed landscape (mix); 29 grids were agricultural dominated land with natural land (An); four grids where classified as agricultural dominated land with urban and natural land, and three grids where classified as natural dominated land with agriculture $(\mathrm{Na})$. The landscape grids are huge (1,600 square kilometers), so it could be variation within every grid, but it gives a rough picture of the Czech landscape composition. 
Engan J. H.: Effect of the landscape types on hunting selection in roe deer (Capreolus capreolus, Linnaeus 1758) trophies in Czech Republic

\section{Fig. 2: Landscapes in Czech Republic}

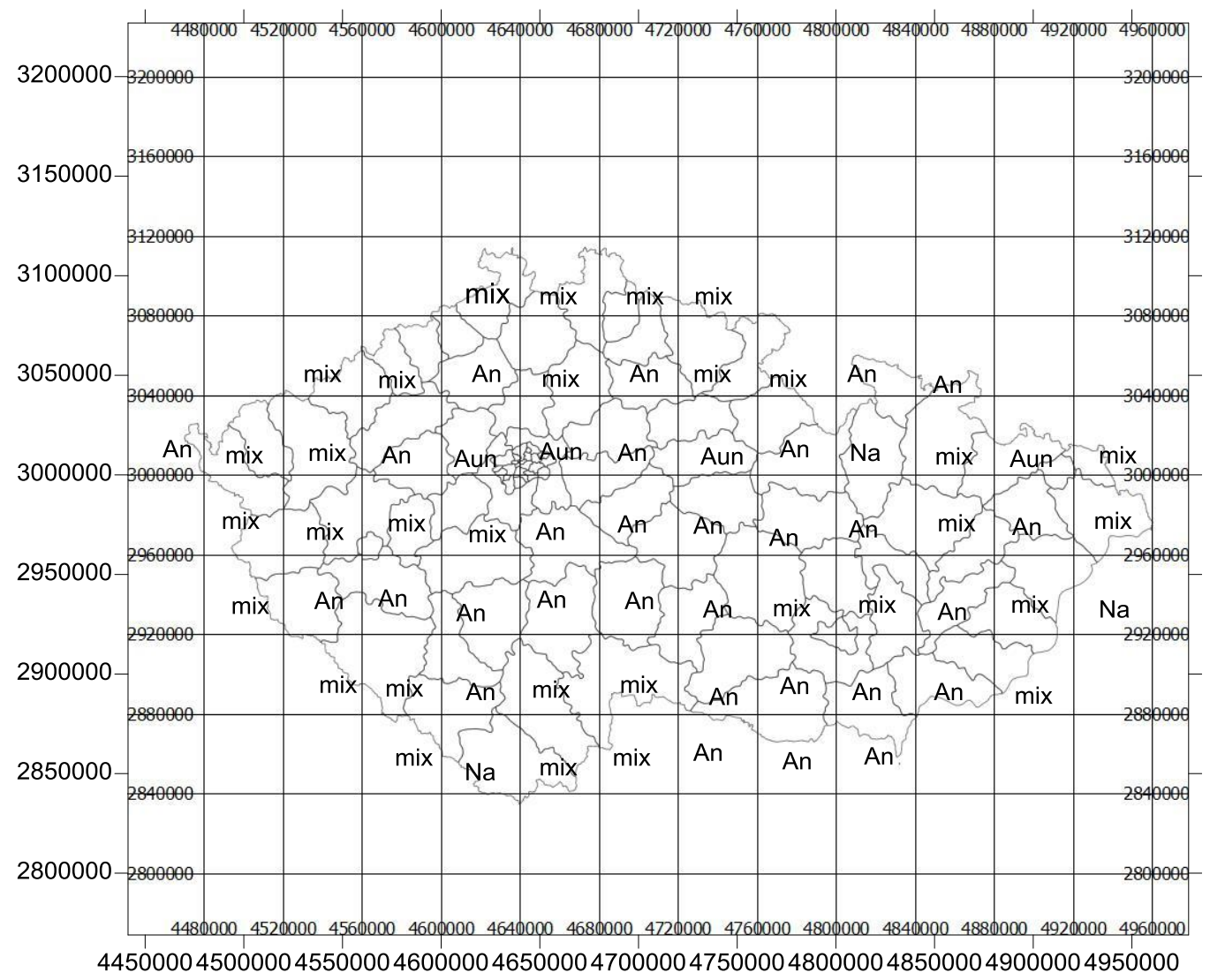

Table 3: Regressions of hunter selection

\begin{tabular}{|l|c|c|c|c|c|c|}
\hline $\begin{array}{l}\text { Regression } \\
\text { age }=\beta \text { cic }+\alpha\end{array}$ & intercept & slope & $\begin{array}{c}\text { Standard } \\
\text { error }\end{array}$ & t-test & -value & $\begin{array}{c}\text { Significant } \\
(\mathrm{p} \text {-value }<0.05)\end{array}$ \\
\hline An & -0.041 & 0.017 & 0.027 & 0.980 & 0.552 & No \\
\hline Aun & -0.008 & -0.047 & 0.047 & -0.963 & 0.336 & No \\
\hline Mix & 0.047 & -0.012 & 0.036 & -0.348 & 0.728 & No \\
\hline Na & 0.117 & 0.080 & 0.178 & 0.350 & 0.727 & No \\
\hline CZ02 & 0.300 & 0.016 & 0.056 & 0.290 & 0.770 & No, but weak trend \\
\hline CZ03 & 0.080 & 0.064 & 0.047 & 1.369 & 0.172 & No \\
\hline CZ04 & -0.038 & 0.004 & 0.079 & 0.046 & 0.963 & No \\
\hline CZ05 & 0.143 & 0.012 & 0.045 & 0.259 & 0.796 & Trend \\
\hline CZ06 & -0.074 & -0.005 & 0.047 & -0.099 & 0.922 & yes \\
\hline CZ07 & -0.241 & -0.073 & 0.041 & -1.761 & 0.079 & -1.994 \\
\hline CZ08 & $-0,042$ & -0.148 & 0.073 & 0.048 & \\
\hline
\end{tabular}




\section{Hunter selection}

Results are shown in Table 3.

The results show no hunters selection in landscape types, or in NUTS regions; however it is a trend in Central Moravia (CZ07) and significant negative selection in Moravia-Silesia. Other regions do not show a trend for hunter selection.

\section{Complementary hunting}

The results are shown in Tables $4 \mathrm{a}, 4 \mathrm{~b}$ and 5 and in Figure 3.

Fig. 3: Trophies in age and quality in the landscape types

a) Landscape: Aun $(n=338)$

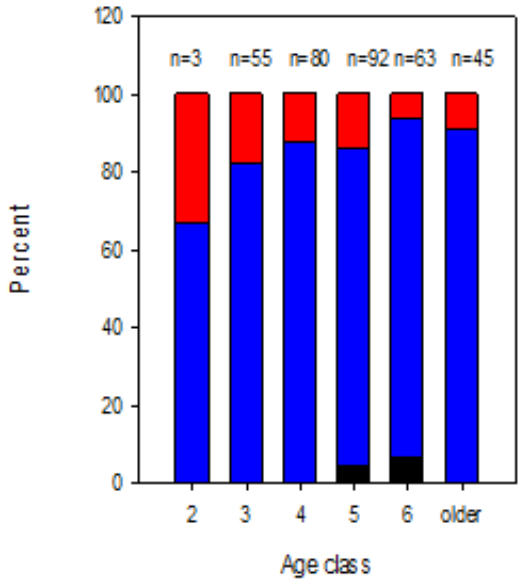

c) Landscape: mixed ( $n=783)$

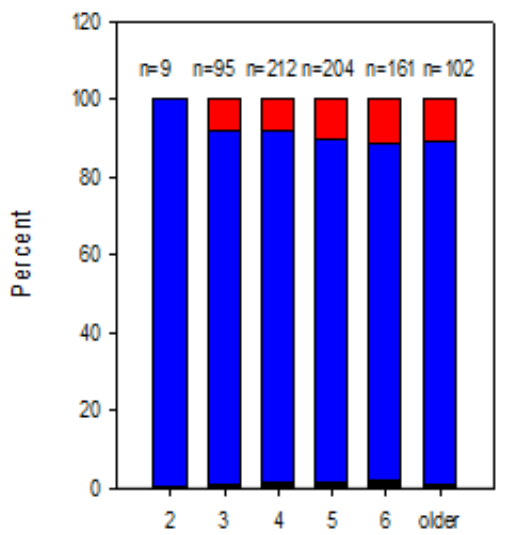

Age dass b) Landscape: An ( $n=1,318$ )

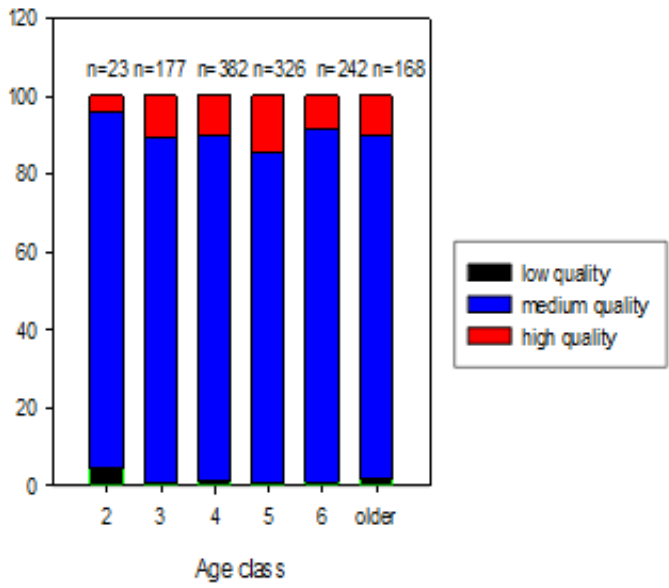

d) Landscape: Na $(n=60)$

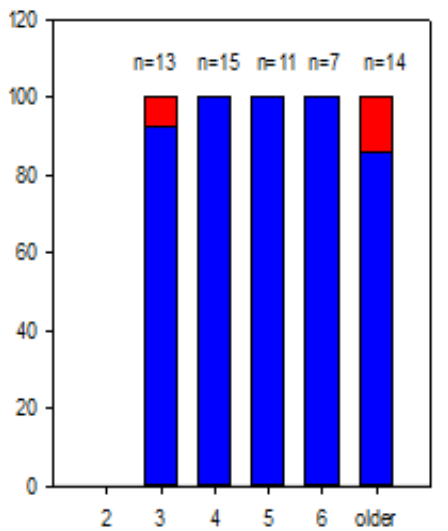

Age dass 
Engan J. H.: Effect of the landscape types on hunting selection in roe deer (Capreolus capreolus, Linnaeus 1758) trophies in Czech Republic

Table 4a: ANOVA compensatory hunting Low quality trophies (compensatory hunting)

\begin{tabular}{|lrrrrr|}
\hline Source of Variation & DF & SS & MS & F & P \\
\hline Landscape & 3 & 14,792 & 4,931 & 3,024 & 0.062 \\
\hline Age & 5 & 13,708 & 2,742 & 1,681 & 0.200 \\
\hline Residual & 15 & 24,458 & 1,631 & & \\
\hline Total & 23 & 52,958 & 2,303 & & \\
\hline
\end{tabular}

The difference in the mean values among the different levels of landscape is not great enough to exclude the possibility that the difference is due only to random sampling variability, after allowing for the effects of differences in age. There is not a statistically significant difference $(\mathrm{P}=0.062)$, however is it a trend.

The difference in the mean values among the different levels of age is not great enough to exclude the possibility that the difference is due only to random sampling variability, after allowing for the effects of differences in landscape. There is not a statistically significant difference $(\mathrm{P}=0.200)$.

Table 4b: High quality trophies (trophy hunting)

\begin{tabular}{|lrrrrr|}
\hline Source of Variation & DF & \multicolumn{1}{c}{ SS } & \multicolumn{1}{c}{ MS } & \multicolumn{1}{c|}{ F } & P \\
\hline Landscape & 3 & 1791,500 & 597,167 & 10,526 & $<0.001$ \\
\hline Age & 5 & 949,333 & 189,867 & 3,347 & 0.031 \\
\hline Residual & 15 & 851,000 & 56,733 & & \\
\hline Total & 23 & 3591,833 & 156,167 & & \\
\hline
\end{tabular}

The difference in the mean values among the different levels of landscape is greater than would be expected by chance, after allowing for effects of differences in age. There is a statistically significant difference $(\mathrm{P}=<0.001)$. A multiple comparison procedure was used to isolate which group(s) differ from the others.

The difference in the mean values among the different levels of age is greater than would be expected by chance, after allowing for effects of differences in landscape. There is a statistically significant difference $(\mathrm{P}=0.031)$.

Table 5: Comparing landscape types and compensatory hunting

\begin{tabular}{|l|l|c|l|l|}
\hline $\begin{array}{l}\text { Comparing landscape } \\
\text { types }\end{array}$ & t-test & $\begin{array}{c}\text { Degrees of } \\
\text { freedom }\end{array}$ & p-value & \\
\hline An vs Aun & 1.484 & 1654 & 0.138 & Trend \\
\hline An vs mix & 0.783 & 2118 & 0.434 & Not significant \\
\hline An vs Na & 1.645 & 1377 & 0.100 & Trend \\
\hline Aun vs mix & 1.949 & 1138 & 0.052 & Strong trend \\
\hline Aun vs Na & 2.101 & 397 & 0.036 & Significant \\
\hline Mix vs Na & 1.418 & 861 & 0.157 & Trend \\
\hline
\end{tabular}




\section{Management hunting selection}

The results are shown in Table 6

Table 6: Management hunting selection

\begin{tabular}{|c|c|c|c|c|c|c|c|c|c|}
\hline $\begin{array}{c}\text { Landscape } \\
\text { type }\end{array}$ & Intercept & slope & Quadratic & SE & t-test & F-ratio & p-value & Stable & $\begin{array}{l}\text { Disruptive or } \\
\text { Stabilisation }\end{array}$ \\
\hline $\begin{array}{c}\text { An } \\
\text { (linear) }\end{array}$ & -15.146 & 0.008 & & 0.004 & 1.689 & & 0.091 & Yes, (x) & \\
\hline $\begin{array}{c}\text { An } \\
\text { (quadratic) }\end{array}$ & -6589.40 & 6.584 & -0.002 & & & 2.951 & 0.053 & & Stabilisation \\
\hline $\begin{array}{c}\text { Aun } \\
\text { (linear) }\end{array}$ & -42.79 & 0.021 & & 0.011 & 1.922 & & 0.055 & Yes, (x) & \\
\hline $\begin{array}{c}\text { Aun } \\
\text { (quadratic) }\end{array}$ & -18646.2 & 18.63 & -0.005 & & & 3.926 & 0.021 & & Stabilisation \\
\hline $\begin{array}{c}\text { Mix } \\
\text { (linear) }\end{array}$ & 13.31 & -0.007 & & 0.006 & 1.087 & & 0.277 & Yes & \\
\hline $\begin{array}{c}\text { Mix } \\
\text { (quadratic) }\end{array}$ & -3452.22 & 3.46 & -0.001 & & & 0.834 & 0.435 & & Stabilisation \\
\hline $\begin{array}{c}\mathrm{Na} \\
\text { (linear) }\end{array}$ & 14.909 & -0.008 & & 0.017 & -0.449 & & 0.449 & Yes & \\
\hline $\begin{array}{c}\mathrm{Na} \\
\text { (quadratic) }\end{array}$ & -14942.6 & 14.95 & -0.004 & & & 0.681 & 0.510 & & Stabilisation \\
\hline
\end{tabular}

$$
\text { ( } \mathrm{x} \text { - but trend for increasing) }
$$

The trophy qualities are stable from year-to-year in all landscape types, however there is a trend for increasing quality in agricultural dominated landscapes (Easier to manage?) The selection is stabilisation in all landscape types.

\section{Depletion hunting selection}

Number of entries per year (harvested trophies) is showed in Figures 4-6 and Table 7.

Table 7: Identification of the breaking point by using piecewise regression

\begin{tabular}{|c|c|c|c|c|c|}
\hline \multicolumn{6}{|c|}{ Results for the Overall Best-Fit Solution: } \\
\hline \multirow{2}{*}{$\begin{array}{l}\mathbf{R} \\
0.8179\end{array}$} & \multirow{2}{*}{$\begin{array}{l}\text { Rsqr } \\
0.6690\end{array}$} & \multicolumn{2}{|c|}{ Adj Rsqr } & \multicolumn{2}{|c|}{ Standard Error of Estimate } \\
\hline & & \multicolumn{2}{|c|}{0.6028} & \multicolumn{2}{|c|}{44,1090} \\
\hline & \multicolumn{2}{|c|}{ Coefficient } & Std. Error & $\mathbf{t}$ & $\mathbf{P}$ \\
\hline y1 & 143,8571 & & 31,9238 & 4,5063 & 0.0004 \\
\hline y2 & 46,3627 & & 22,1444 & 2,0937 & 0.0537 \\
\hline y3 & 241,0000 & & 23,1194 & 10,4241 & $<0.0001$ \\
\hline $\mathrm{T} 1$ & 1995,6872 & & 1,3671 & 1459,7584 & $<0.0001$ \\
\hline \multicolumn{6}{|c|}{ Analysis of Variance: } \\
\hline \multicolumn{2}{|r|}{ DF } & & SS & \multicolumn{2}{|l|}{ MS } \\
\hline \multicolumn{2}{|c|}{ Regression 4} & 3895 & 19,8956 & 97379,9739 & \\
\hline Residual & 15 & 291 & 84,1044 & 1945,6070 & \\
\hline Total & 19 & 4187 & 04,0000 & 22037,0526 & \\
\hline
\end{tabular}


Engan J. H.: Effect of the landscape types on hunting selection in roe deer (Capreolus capreolus, Linnaeus 1758) trophies in Czech Republic

\begin{tabular}{|lccccc|}
\hline \multicolumn{7}{|l|}{ Corrected for the mean of the observations: } \\
\hline \multicolumn{7}{|c}{ DF } & SS & MS & F & P \\
\hline Regression & 3 & 58991,6851 & 19663,8950 & 10,1068 & 0.0007 \\
\hline Residual & 15 & 29184,1044 & 1945,6070 & & \\
\hline Total & 18 & 88175,7895 & 4898,6550 & & \\
\hline
\end{tabular}

Decreasing in the period 1990-1995, and increasing in the period 1996-2008.

Fig. 4: Number of entries between 1990-2008, the slope marking the breaking point in 1996

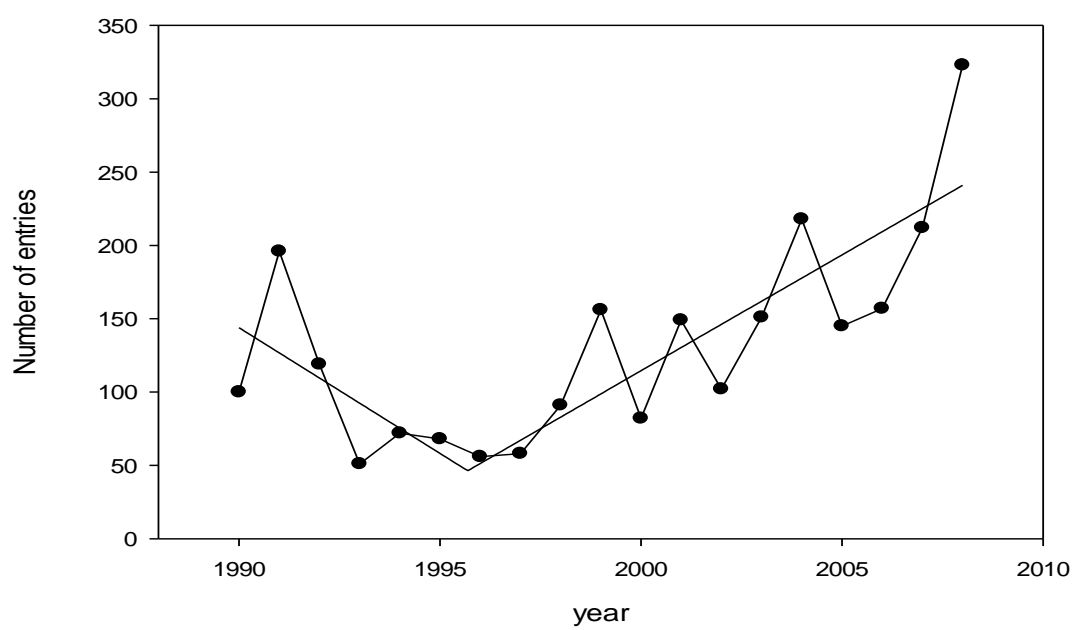

ANCOVA period 1990-1995

Fig. 5: Adjusted Means with 95\% Confidence Intervals

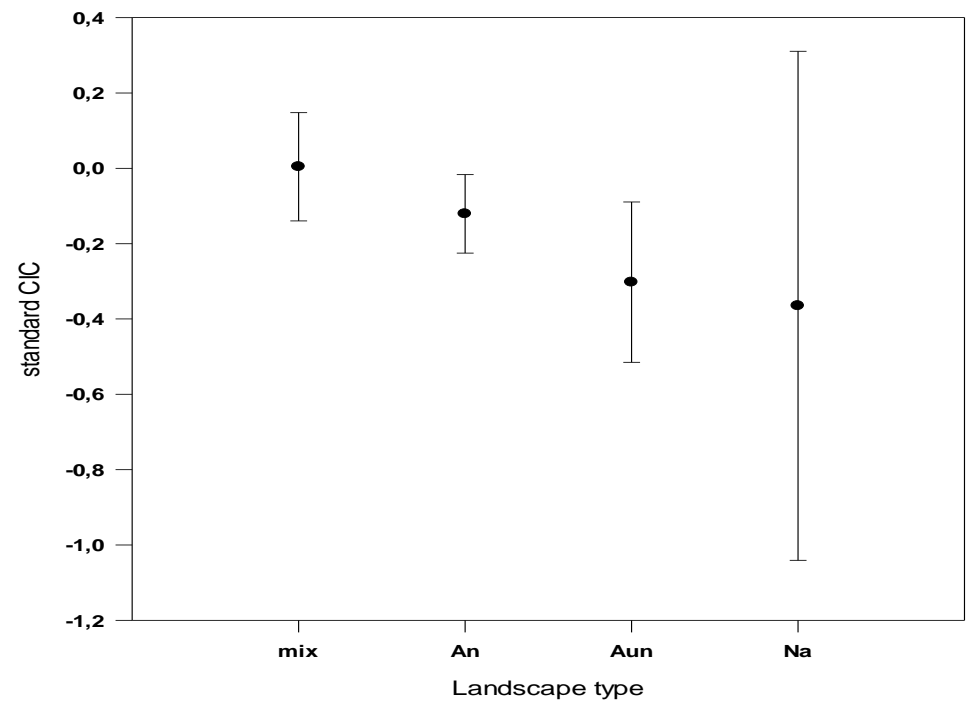


There are no significant differences between landscape types during the period 1990-1995. ANCOVA: period between 1996-2008

Fig. 6: Adjusted Means with 95\% Confidence Intervals

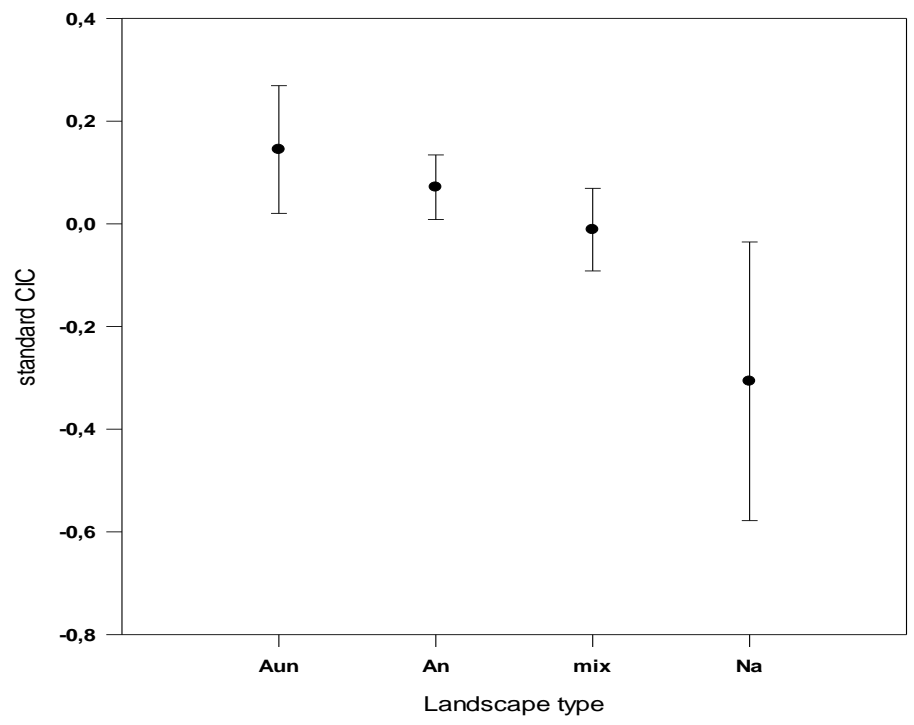

Natural land shows negative slope during the decreasing and increasing periods; this is some indication for depletion in this landscape type.

Hunting pressure hunting selection 1990-1995 (decreasing hunting pressure)

Young bucks (below 4 years old)

\begin{tabular}{|c|c|c|c|c|c|c|c|c|}
\hline Period & Age group & Landscape & intercept & slope & SE & t-test & $\mathrm{p}$-value & $\begin{array}{l}\text { Significant } \\
(p<0.05)\end{array}$ \\
\hline \multirow{12}{*}{$\begin{array}{l}1990-19 \\
95\end{array}$} & \multirow{4}{*}{$\begin{array}{l}\text { Young } \\
(\text { age< } 4 \\
\text { years })\end{array}$} & An & 309.85 & -0.156 & 0.090 & -1.728 & 0.090 & trend \\
\hline & & Aun & 1.843 & -0.001 & 0.146 & -0.007 & 0.995 & No \\
\hline & & Mix & -577.66 & 0.290 & 0.202 & 1.434 & 0.177 & trend \\
\hline & & $\mathrm{Na}$ & \multicolumn{6}{|c|}{$\begin{array}{l}\text { Due to few observations, the analysis was not able to be carried out } \\
\text { during this period }\end{array}$} \\
\hline & \multirow{4}{*}{$\begin{array}{l}\text { Medium (4 } \\
\text { and } 5 \\
\text { years old) }\end{array}$} & An & 20.15 & -0.010 & 0.050 & -0.203 & 0.839 & No \\
\hline & & Aun & -163.99 & 0.082 & 0.090 & 0.908 & 0.370 & No \\
\hline & & Mix & 257.88 & $-0,129$ & 0.052 & -2.032 & 0.046 & yes \\
\hline & & $\mathrm{Na}$ & -296.48 & 0.149 & 0.097 & 1.531 & 0.223 & No \\
\hline & \multirow{4}{*}{$\begin{array}{l}\text { Old }(\text { age } \\
>6 \text { years }\end{array}$} & An & -82.34 & 0.041 & 0.052 & 0.816 & 0.416 & no \\
\hline & & Aun & -35.10 & 0.017 & 0.136 & 0.129 & 0.899 & no \\
\hline & & Mix & 38.99 & -0.020 & 0.077 & $-0,253$ & 0.801 & No \\
\hline & & $\mathrm{Na}$ & $-11,78$ & 0.006 & 0.130 & 0.043 & 0.973 & No \\
\hline
\end{tabular}


Engan J. H.: Effect of the landscape types on hunting selection in roe deer (Capreolus capreolus, Linnaeus 1758) trophies in Czech Republic

1996-2008 (increasing hunting pressure)

\begin{tabular}{|c|c|c|c|c|c|c|c|c|}
\hline Period & Age group & Landscape & intercept & slope & $\mathrm{SE}$ & t-test & p-value & $\begin{array}{l}\text { Significant } \\
(\mathrm{p}<0.05)\end{array}$ \\
\hline \multirow{12}{*}{$\begin{array}{l}1996-20 \\
08\end{array}$} & \multirow{4}{*}{$\begin{array}{l}\text { Young } \\
(\text { age }<4 \\
\text { years })\end{array}$} & An & 45.898 & -0.023 & 0.021 & --1.091 & 0.277 & no \\
\hline & & Aun & 189.68 & -0.095 & 0.047 & -2.017 & 0.051 & Strong trend \\
\hline & & Mix & 45.737 & -0.023 & 0.021 & -1.112 & 0.269 & No \\
\hline & & $\mathrm{Na}$ & 2.155 & -0.001 & 0.078 & -0.016 & 0.988 & No \\
\hline & \multirow{4}{*}{$\begin{array}{l}\text { Medium } \\
\text { (4 and } 5 \\
\text { years old) }\end{array}$} & $\mathrm{An}$ & 32.96 & -0.016 & 0.013 & -1.305 & 0.193 & trend \\
\hline & & Aun & -5.60 & 0.029 & 0.009 & 0.100 & 0.921 & No \\
\hline & & Mix & 39.48 & -0.029 & 0.016 & -1.232 & 0.219 & No \\
\hline & & $\mathrm{Na}$ & 24.45 & -0.012 & 0.028 & -0.447 & 0.660 & No \\
\hline & \multirow{4}{*}{$\begin{array}{l}\text { Old (age } \\
>6 \text { years }\end{array}$} & An & 35.13 & -0.018 & 0.017 & -1.015 & 0.311 & No \\
\hline & & Aun & 67.00 & -0.033 & 0.037 & -0.908 & 0.367 & No \\
\hline & & Mix & 40.71 & -0.020 & 0.019 & -1.056 & 0.292 & No \\
\hline & & $\mathrm{Na}$ & 73.265 & -0.037 & 0.044 & -0.836 & 0.416 & No \\
\hline
\end{tabular}

8 out of 11 shows a more negative slope in the increasing period, so the hypothesis is partially supported.

Correlation matrix hunting selection coefficients (HUNS) vs landscape factors and landscape indexes

\begin{tabular}{|c|c|c|c|c|c|c|c|c|c|}
\hline & $\begin{array}{c}\% \\
\text { Urban }\end{array}$ & $\begin{array}{c}\% \\
\text { Agriculture land }\end{array}$ & $\begin{array}{c}\% \\
\text { Forest }\end{array}$ & $\begin{array}{c}\text { Other } \\
\text { natural } \\
\text { land }\end{array}$ & $\begin{array}{c}\% \\
\text { Water }\end{array}$ & $\begin{array}{c}\text { Edge } \\
\text { density }\end{array}$ & $\begin{array}{c}\text { Patch } \\
\text { density }\end{array}$ & $\begin{array}{c}\text { Mean } \\
\text { patch } \\
\text { size }\end{array}$ & $\begin{array}{c}\text { Shannon } \\
\text { diversity } \\
\text { index }\end{array}$ \\
\hline HUNS & -0.243 & -0.076 & 0.111 & 0.191 & -0.010 & 0.013 & -0.096 & 0.268 & 0.051 \\
\hline
\end{tabular}

The results show negative hunter selection in areas with high occurrence of urban areas, agricultural areas and high patch density. Positive hunting selection was identified in areas with high occurrence of forest, other natural land and how diverse the landscape is.

\section{DISCUSSION}

In recent years, there have been several studies concerning the topic of hunting selection (examples include Mysterud, 2011, 2007; Rivrud et al., 2013; Hedrick, 2012; Festa Bianchet, 2003). One of the most complete studies, Rivrud et al. (2013), concerning a long term study of red deer in Hungary, identified a support for hunter selection since trophy hunters shoot larger males. In this study, it was found that foreign hunters took 76.36 percent of harvested 9 year old bucks, although there was considerable variation. A study by Festa-Bianchet, however, claims that horn size in big horn rams (Ovis canadiensis), was decreased by hunter selection.

In this study, significant hunter selection was not identified in the landscape types; within the Moravia-Silesia region there was a negative hunter selection, in central Moravia NUTS region there was a trend for negative hunter selection, and in Southwest Bohemia there was a trend for increasing quality by hunter selection. Mysterud (2011) examined 26 studies in the literature and only three of these studies lead to directional selection. Monteith et al. (2013) analysed different game species under the Boone and Crocket system used in North America, and found positive temporal trends in Canada moose (Alces a. americana and A.a.andersoni), Muskox (Ovibovis moschatus), Pronghorn (Antilocapra americana), and Rocky mountain goat (Oreamnos americanus). Other horned and antlered game showed 
negative trends, but found no support for desire to submit smaller, yet eligible trophies, but found a support for selective harvest against genes for large trophy specimens. The results show a negative correlation between hunter selection coefficients and the occurrence of urban areas, agricultural areas and patch density. Within agricultural areas, the landscape is open and the hunter would have time to take a selective decision before shooting an animal. Higher patch density will not give the roe deer enough cover, and if the hunter is waiting close to the paths between the patches, he could have enough time to take a selective shot. Urban areas, however, or more precisely closeness to urban areas, or other artificial constructions, enable the hunter to access the hunting grounds more easy and spend more time in the field. In the forests, the time for selection is shorter; however, there is also a target for the gamekeeper to increase the quality of game within forest habitat. Patch size will provide more cover and reduce the time for selection. There are surprisingly few studies concerning the landscape effect of selective hunting. Mysterud et al. (2006) found a difference between local and foreign roe deer hunters in Poland; local hunters were hunting within closer proximity to the forest than foreign hunters, which preferred agricultural areas. However, more research is necessary, especially in the species mouflon and red deer that are the most attractive game species in Czech Republic.

The Czech act of game management supports compensatory hunting, and the Czech Moravian hunting association (CMMJ) described the criteria for breeding (Babička et al., 2007). This study supports this, however, there is a difference between the landscape types, where agricultural land differs from mixed landscape and natural landscape. A possible explanation for this could be that it is easier to manage roe deer in the agricultural landscape, or that the agricultural landscape is more attractive to roe deer hunters than other landscapes. A combination of both theories is likely, because there are more roe deer in the agricultural landscape and therefore a higher probability for a successful hunt. Due to the openness of the landscape, the gamekeepers can more easily select bucks for breeding. That does not mean that the hunter cannot select a large trophy buck, but it is expensive, a gold medal buck in Czech Republic costing in excess of 2000 euro (http://elovni.cz). Rivrud et al. (2013) found that, in Hungary, foreign hunters harvest larger stags than local hunters. Hungary has much of the same hunting rules and hunting traditions as Czech Republic. Mysterud \& Bischoff (2010) developed a model for compensatory hunting without negative effects of trophy hunting, where low quality individuals can be harvested during an early life stage to facilitate sustainable trophy hunting. Babička et al. (2007) shows this in practice.

Trophy quality was consistent from year-to-year, however in in the agricultural areas there is a trend for increasing trophy quality. It is also suggested that the stability is a result of stabilisation selection, not disruptive selection. Rivrud et al. (2013) supported this, particularly in Hungary, but with periods of decline, it was not always the case.

In the period 1990 to 1995 there was a declining in number of entries, which could be an effect of decreasing population. In 1996 to 2008 the population increased. This followed a decrease in hunting pressure between 1990-1995, which subsequently increased during 1996 to 2008. Differences between or within landscape types were not found with respect to depletion, so the depletion hypothesis is therefore rejected. The same was found during a red deer study in Hungary (Rivrud et al., 2013). During 1990 to 1995, in young bucks there was a negative trend in the agricultural dominated with natural landscape, but in mixed landscape there was a positive trend in younger bucks. In medium aged bucks in a mixed landscape, there was a significant decline. In the period 1996 to 2008 there was negative trend in young bucks in agricultural dominated land with natural and urban, and medium sized bucks in agriculture dominated land with natural land. However, 8 of 11 age/landscape classes did 
have a stronger negative trend in the period 1996 to 2008, so the hunting pressure hypothesis cannot be rejected, but neither supported.

\section{Other factors}

Environmental selection can also affect antler quality. Climatic variation, especially severe winters (cold and snowy winters) will decrease the surplus of antler development, and mild winters will increase the antler quality. Heldrick (2012) analysed desert big horn, and the decline was not only caused by hunting selection, but also variation of rainfall and inbreeding depression. Other factors could be population dynamics, where high density produced more density-dependent competition and lower trophy quality. This is because changes in the landscape (namely changes in land use) will affect the quality of habitats; like home range, nutrient quality and cover, however more research is required to investigate this topic. Josef Hromas (1998) investigated what could have effects on trophies in the former Czechoslovakia; soil type, forest type, climate (temperature, precipitation, days of snow cover, snow depth, clear days and length of growth season) will all affect the development of trophy specimens.

An interesting question is; can researchers use trophy books as a source to investigate trends in populations. Pellitier et al. (2012) claims that data from selective harvest underestimate temporal trends in quantitative traits. This question was discussed at the $60^{\text {th }}$ CIC general assembly in Budapest in 2013, and Professor Csanyi (pers. comm. 2013) claimed that the trophy books can be used; they are biased, but contain valuable data, which can be used over successive years.

\section{Implications for management and conclusion}

The effect of trophy hunting has grown to be an important field of wildlife biology the last decade. The works of Professor Mysterud and Professor Festa-Bianchet have been important in increasing understanding of this topic. However, all the processes work together in management of game species, and it is desirable to make a model that takes population dynamics, habitat quality, landscape ecology, climate data and hunting selection into consideration. It could be expressed by making a structural equation model (SEM). Using this model, it is possible to make decisions at a local or regional level with respect to trophy quality. The landscape will have an effect on selective hunting, and open areas like agricultural areas will make it easier to make decisions. However, more research is necessary to understand the dynamics between game management and landscape ecology.

\section{ACKNOWLEDGEMENTS}

I wish to thank Ing. Ludek Kralicek, Czech- Moravian Hunting Association, for data.

\section{REFERENCES}

Babička, C., Králíček, L., Knápek, M., (2007). Chovatelské přehlidky-metodika. Retrieved April 26, 2008, from www.myslivost.cz, 24 pp. (in Czech).

Bartoš, L. (2010). Ungulates and their management in Czech Republic. In Appolonio M, Andersen, R and Putman, R.: European Ungulates and their management in the $21^{\text {st }}$ century. (pp. 243-261), Cambridge University Press, Cambridge. 
Červený, J, Kamler, J, Kholová, H, Koubek, P, Martinová, N. (2009). Encyklopedie Myslivost. Vydalo Ottovo Nakladatelstvi s.r.o. Praha, Czech Republic, 591 pp. (in Czech).

CMMJ (1993). Katalog Trofeji, Ceske Budejovice 1993, 127 pp.

CMMJ (1996). Katalog Trofeji, Lysa nad Labem, Natura Viva 1996, 110 pp.

CMMJ (2000). Katalog Hodnoceni Trofeji, Lysa nad Labem, Natura Viva 2000, 168 pp.

CMMJ (2005). Katalog Hodnoceni Trofeji, Lysa nad Labem, Natura Viva 2005, 160 pp.

CMMJ (2009). Katalog Hodnoceni Trofeji, Lysa nad Labem, Natura Viva 2009, 184 pp.

Coltman, D.W., O'Donoghue, P, Jorgenson, J.T., Hogg, J.T.,Strobeck,C. and Festa-Bianchet, M. (2003). Undesirable evolutionary consequences of trophy hunting. Nature (426) 655-658. Retrieved December 11, 2003, from doi:10.1038/nature02177.

Czech Ministry of Agriculture (2001). Game management act 449/2001, Praha. Retrieved Januar 6, 2002, from http://eagri.cz/public/web/file/10643/game_management_act.pdf.

Estreguil,C, Caudullo G. and Whitmore C.(2012). Habitat landscape pattern and connectivity indices, Alterra Report 2297, Alterra, Wageningen, The Netherlands, 80 pp.

Festa-Bianchet, M. (2003). Exploitative Wildlife Management as a Selective Pressure for Life-History Evolution of Large Mammals, In Festa-Bianchet M., and Apollonio M., Animal Behavior and Wildlife Conservation (pp. 191-207).

Hedrick, P.W. (2012). Rapid decrease in horn size of bighorn sheep: environmental decline, inbreeding depression, or evolutionary response to trophy hunting? J Hered.(6):770-81. doi: 10.1093/jhered/esr082.

Hromas, J. (1998). Nejsilnejii Svĕtové Trofeje, Die Stärksten Trophäen der Welt. Vydala, Matice lesnická s.r.o, Pisek, Czech Republic. 260 pp. (in Czech and German).

Csanyi, S, (2013). Lecture note: Final discussion, April $29^{\text {th }}$, Selective Hunting, CIC $60^{\text {th }}$ General Assembly, Marriott Hotel, Budapest.

Monteith, K., Long, R.A., Bleich, V.C., Heffelfinger, J.R., Krausman, P.R., Bowyer, R.T. (2013). Effects of harvest, culture, and climate on trends in size of horn-like structures in trophy ungulates. Wildlife Monographs (183)1-28, DOI: 10.1002/wmon.1007.

Mysterud A. and Bischof R. (2010). Can compensatory culling offset undesirable evolutionary consequences of trophy hunting? Journal of Animal Ecology (79) 148-160.

Mysterud, A. (2011). Selective harvesting of large mammals: how often does it result in directional selection? Journal of Applied Ecology (48) 827-834 DOI: 10.1111/j.1365 -2664.2011.02006.x.

Mysterud, A., Tryhanowski, N., Panek, M. (2006). Selectivity of harvesting differs between local and foreign roe deer hunters: trophy stalkers have the first shot at the right place. Biology letters (2) 632-635, doi: 10.1098/rsb1.2006.0533.

Pelletier, F., Festa-Bianchet, M. and Jorgenson, J.T. (2012). Data from selective harvests underestimate temporal trends in quantitative traits. Biol. Lett. (8) 878-881. doi:10.1098/rsbl. 2011.1207.

Quantum GIS (2014). Quantum GIS 2.4, GIS software.

Rivrud, I.M., Sonkoly, K., Lehoczki, R., Csanyi, S., Storvik, G.O., Mysterud, A. (2013). Hunter selection and long-term trend (1881-2008) of red deer trophy sizes in Hungary. Journal of applied Ecology 50 (1), 168-180, DOI: 10.1111/1365-2664.12004.

SigmaPlot (2014). SigmaPlot version 13.0. Retrieved December 6, 2014, from Graphical/ statistical software. 
SYSTAT Inc (2010). SYSTAT 13, statistical software.

Vanpé, C., Gaillard, J-M., Kjellander, P., Mysterud, A., Magnien, P., Delorme, D., Van Laere, G., Klein, F., Liberg, O. \& Hewison, A.J.M. (2007). Antler size provides a honest signal of male phenotypic quality in roe deer. The American Naturalist 169(4):481-493.

Varicak, V. (2007). Trophäen Bewertung der Europäischen Wildarten. Edition Hubertus, AV BUCH , Vienna, Austria, 140 pp. (in German).

Walsh, B. (2007) Evolutionary Quantitative Genetics, In Balding, D.J., Bishop, M. and Cannings, C.: Handbook of Statistical Genetics (pp 533-586), Volume 1, $3^{\text {rd }}$ edition. Wiley. $751 \mathrm{pp}$,

Whitehead, K.G., Hettier de Boislambert, A.J., Trense, W. (1981). The game-trophies of the world/Les trophées de chasse du monde/Die Jagdtrophäen der Welt. Verlag Paul Parey, Hamburg, Berlin, Germany. 160 pp. (in English, French and German).

\section{Electronic catalogue:}

http://www.myslivost.cz/Pro-myslivce/Informace-pro-myslivce/Katalog-trofeji

Hunting in Czech Republic: http://elovci.cz/cs/nabidky/seznam/1

Hunting grounds: http://apps.hfbiz.cz/apps/mysliveckyportal/honitby/view/

Datum converter: http://epsg.io/3035/map 


\section{APPENDIX}

Corine Land Cover

\begin{tabular}{|c|c|c|c|}
\hline CODE & DESCRIPTION & classified to & in $\mathrm{CZ}$ ? \\
\hline 111 & Continuous urban fabric & urban & yes \\
\hline 112 & Discontinuous urban fabric & urban & yes \\
\hline 121 & Industrial or commercial units & urban & yes \\
\hline 122 & Road and rail networks and associated land & urban & yes \\
\hline 123 & Port areas & urban & yes \\
\hline 124 & Airports & urban & yes \\
\hline 131 & Mineral extraction sites & urban & yes \\
\hline 132 & Dump sites & urban & yes \\
\hline 133 & Construction sites & urban & yes \\
\hline 141 & Green urban areas & urban & yes \\
\hline 142 & Sport and leisure facilities & urban & yes \\
\hline 211 & Non-irrigated arable land & agriculture & yes \\
\hline 212 & Permanently irrigated land & agriculture & yes \\
\hline 213 & Rice fields & agriculture & no \\
\hline 221 & Vineyards & agriculture & yes \\
\hline 222 & Fruit trees and berry plantations & agriculture & yes \\
\hline 223 & Olive groves & agriculture & no \\
\hline 231 & Pastures & agriculture & yes \\
\hline 241 & $\begin{array}{l}\text { Annual crops associated with permanent } \\
\text { crop }\end{array}$ & agriculture & yes \\
\hline 242 & Complex cultivation patterns & agriculture & yes \\
\hline 243 & $\begin{array}{l}\text { Land occupied by agriculture, with some of } \\
\text { natural vegetation }\end{array}$ & agriculture & yes \\
\hline 244 & Agro-forestry areas & agriculture & no \\
\hline 311 & Broad-leaved forest & agriculture & yes \\
\hline 312 & Coniferous forest & forest & yes \\
\hline 313 & Mixed forest & forest & yes \\
\hline 321 & Natural grasslands & forest & yes \\
\hline 322 & Moors and heathland & other natural land & yes \\
\hline 323 & Sclerophyllous vegetation & other natural land & yes \\
\hline 324 & Transitional woodland-shrub & other natural land & yes \\
\hline 331 & Beaches, dunes, sands & other natural land & yes \\
\hline 332 & Bare rocks & other natural land & yes \\
\hline 333 & Sparsely vegetated areas & other natural land & yes \\
\hline
\end{tabular}


Engan J. H.: Effect of the landscape types on hunting selection in roe deer (Capreolus capreolus, Linnaeus 1758) trophies in Czech Republic

\begin{tabular}{|r|l|l|l|}
\hline CODE & DESCRIPTION & classified to & in CZ ? \\
\hline 334 & Burnt areas & other natural land & yes \\
\hline 335 & Glaciers and perpetual snow & other natural land & no \\
\hline 411 & Inland marshes & other natural land & yes \\
\hline 412 & Peat bogs & other natural land & yes \\
\hline 421 & Salt marshes & other natural land & no \\
\hline 422 & Salines & other natural land & no \\
\hline 423 & Intertidal flats & other natural land & no \\
\hline 511 & Water courses & water & yes \\
\hline 512 & Water bodies & water & yes \\
\hline 521 & Coastal lagoons & water & no \\
\hline 522 & Estuaries & water & no \\
\hline 523 & Ocean & water & no \\
\hline & & & \\
\hline
\end{tabular}

Antler characteristics in Czech Republic used in this study.

CIC measurement:

Mean: 115.46

Standard deviation: 10.26 